\title{
How Teachers Comprehend and Support Children's Needs to be Scientists
}

\author{
Anita Yus \\ Lecturer in the Department of Teacher Education Early Childhood Education \\ Faculty of Education, Universitas Negeri Medan \\ Medan, Indonesia \\ Corresponding e-mail: anitayus@ymail.com
}

\begin{abstract}
This paper talks about a research result conducted to investigate how twelve teachers of early childhood program comprehend the constructivist theory of Piaget, and how they inquire, how the children acquire and construct a number of knowledge through occurred interactions. This is a qualitative research with an observation method followed up by a focus group discussion (FGD). The research result shows that there is a reciprocal interaction between the behaviours of teachers and children affected by the size of the classroom and learning source, teaching experiences, education background, teachers' attitude and motivation, as well as the way the teachers interpret and support the children's needs. The teachers involved in this research came up with varied perspective on how knowledge acquired by children at first and how they construct it. This research brings a new perspective in understanding children as scientists.
\end{abstract}

Keywords: constructivist approach, young children as a scientist, teacher practice, teacher education.

\section{INTRODUCTION}

The needs for education and science have been thriving in the societies. The societies and parents dream for their children to have broad knowledge and to quickly become smarter. Such needs have transformed into demands against Early Childhood Education (Pendidikan Anak Usia Dini/PAUD). Such demands should not have become a problem because early childhood students possess the characteristics of active learners. Such characteristics play a significant contribution to the development of the children's learning interests which is extremely important in this early childhood period (Bowman, Eds.2001).

The development of needs of the parents and societies on early childhood education institutions significantly impacts the growth of such institutions. There has been an annual growth of $16 \%$ of the number of the institutions. In line with such growth, some critics have surfaced against the learning activities in the institutions. In the learning activities, the children tend to be passive and to lean towards following the teachers' instructions (Gunawan,
2004). Learning activities are dominated by completing the worksheets; they are mechanistic and academic in nature (Supriadi, 2004), and that they transform the children in becoming robots.

This research studies the learning activities in early childhood education institutions, namely the activities that the teachers and children do in the learning process and how to assist the early childhood students in gaining the knowledge, developing their thinking capability, and developing their process skills especially in the context of the children's characteristics as young scientists (Christine \& Lory, 2003).

\section{LITERATURE REVIEW}

\section{1) The Characteristics of Early Childhood Students and the Gaining of Science}

Early childhood students are individuals that attract everybody's attention due to several characteristics such as their unique personalities and the vast amount of curiosity (Feeney, Christensen, and Moravik, 2006). These characteristics make them to be known as active individuals. Therefore, 
early childhood students require activities, involvement and planned or spontaneous learning experiences.

Ever since infancy, children have conducted various activities including science activities. They observe and respond to the daily phenomena. Each child learns about his or her environment through his or her senses of sights, sounds, touches, aromas, and tastes (Shannan, 2006). Through these processes, the children gain the knowledge on the existence of something, such as knowing themselves, their mothers, sounds, tastes, soft and rough textures, and other things although the children are not yet capable in expressing them. In other words, the early childhood students may gain their own sciences naturally from their environments.

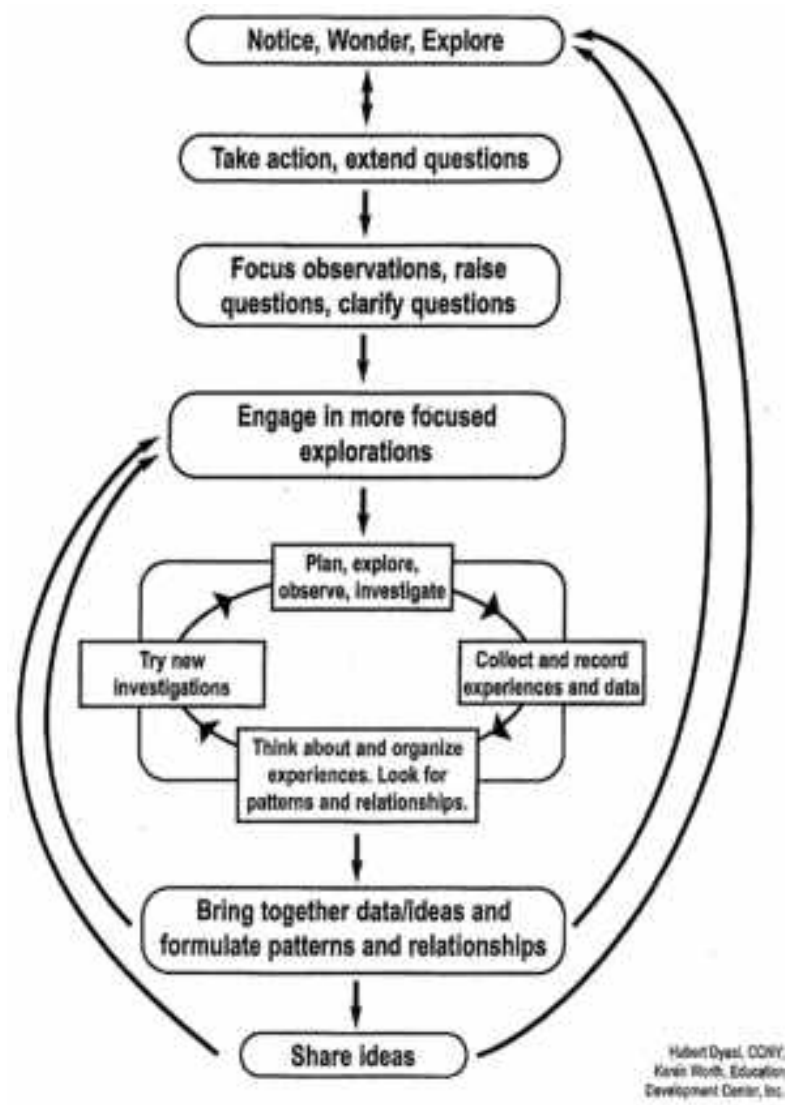

Figure 1. Science learning cycle (Karen, 2010)

Science serves as knowledge and life's needs of every individual. For early childhood students, science is not only important for introducing them to life as young scientists and as cognitive development; science is also important in developing the skills, basic attitude, and learning interests. Constructivist perspectives put the emphasis on the idea that knowledge is gained by yourself (Kauchack \& Paul, 2008).

\section{2) Characteristics and Roles of the Teachers in Science Learning}

Science is a body of knowledge and it consists of facts, concepts, principles, laws, theories, and models in explaining all events or nature's ways of working and it also serves as learning and discovering processes (Karen, 2010). Science as we are defining it is thus quite broad; it involves experimentations, creativity, and problem solving, all of which come into play as children try to understand the world (Christine \& Britain, 2003). Scientists are individuals involved in the investigation process to magnify and to attempt to answer the questions about nature. Science and scientific inquiry serve as a learning cycle for early childhood students and as guidance for teachers to facilitate the children in Figure 1 (Karen, 2010).

Teaching is defined as an interaction of all learning components (Dunkin \& Biddle, 1974; Snelbecker, 1974) and that all components interact with one another (Kemp, 1985), with the emphasis on the environmental setting (Joyce \& Weil,1996). The teacher is an active facilitator, setting up educational contexts, carefully observing young children as they engage in learning, interacting when and where this encourages theory building, modifying the environment and activities based on what children do and how they interact, and supporting children in their interactions with others (Christine \& Britain, 2003). The quality of interaction is influenced by the size of the class and the learning resources, teaching experience, educational background, the attitude and perception of the teachers and how they interpret and support the needs of the children (Dunkin \& Biddle, 1974).

The roles of the teacher in science learning through a constructivist approach are realized in the forms of activities (Christine \& Britain, 2003). The activity formats for each role is outlined in this Table 1 .

Table 1.Teacher activities according to his or her roles

\begin{tabular}{lll}
\hline No & \multicolumn{1}{c}{ Roles } & \multicolumn{1}{c}{ Activities } \\
\hline 1 & $\begin{array}{l}\text { Preparing the } \\
\text { materials in } \\
\text { science learning }\end{array}$ & $\begin{array}{l}\text { Presenting the materials, } \\
\text { choices, offering activities, } \\
\text { putting up ideas to continue the } \\
\text { activities }\end{array}$ \\
\hline
\end{tabular}


Table 1. Cont.

\begin{tabular}{|c|c|c|}
\hline 2 & $\begin{array}{l}\text { Observing the } \\
\text { children }\end{array}$ & $\begin{array}{l}\text { Observing what the children are } \\
\text { doing, listening to what they are } \\
\text { saying to discover their interests, } \\
\text { needs, and understandings }\end{array}$ \\
\hline 3 & Asking questions & $\begin{array}{l}\text { Asking guided questions and } \\
\text { other questions that will } \\
\text { encourage the children to look at } \\
\text { the problem of the object }\end{array}$ \\
\hline 4 & $\begin{array}{l}\text { Organizing the } \\
\text { environment }\end{array}$ & $\begin{array}{l}\text { Placing the materials in indoor } \\
\text { our outdoor environment, or both }\end{array}$ \\
\hline 5 & $\begin{array}{l}\text { Managing the } \\
\text { social interaction }\end{array}$ & $\begin{array}{l}\text { Placing the children in the } \\
\text { suitable class according to the } \\
\text { proportion of teachers, students, } \\
\text { and materials. }\end{array}$ \\
\hline 6 & Documenting & $\begin{array}{l}\text { Compiling, organizing, utilizing, } \\
\text { and sharing information related } \\
\text { to early childhood education for } \\
\text { the development of the children }\end{array}$ \\
\hline 7 & $\begin{array}{l}\text { Developing the } \\
\text { learning culture }\end{array}$ & $\begin{array}{l}\text { Managing the behavior of each } \\
\text { individual in learning to develop } \\
\text { the learning habit. }\end{array}$ \\
\hline 8 & $\begin{array}{l}\text { Drawing up } \\
\text { conclusions of } \\
\text { the theories }\end{array}$ & $\begin{array}{l}\text { Becoming the scientist in } \\
\text { learning }\end{array}$ \\
\hline
\end{tabular}

\section{RESEARCH METHODOLOGY}

This research uses the qualitative method. Data is compiled using the observation methods of checklist instrument and anecdotal record in order to observe the implementation of the science learning or activities, and how the children gain their knowledge and play the role of young scientists. Interviews were conducted to discover the attitude and motivation of conducting the science learning activities and for collection of data, which was then followed by the Focus Group Discussion (FGD) method consisting of 12 (twelve) teachers' Kindergarten, and assisted by fellow university lecturers participating in collecting the data. This research is aimed at discovering the understanding of kindergarten teachers about the constructivist theory which was developed by Piaget and its implementation in learning, how the teachers assist the children in interacting with the teachers and other children, how the teachers ask questions, and how the children obtain and construct the amount of knowledge through such interactions. The data coming from the anecdotal record was then analyzed using the qualitative method to observe the understanding of the teachers on the constructivist theory which was developed by Piaget, how the teachers assisted the children in interacting with the teachers and other children, how the teachers asked the questions, and how the children obtained and constructed the amount of knowledge through such interactions. The data coming from the checklist was then analyzed by the percentage analysis technique to observe the differences of the teachers' roles in understanding and supporting the children as scientists based on the size of class and learning resources, teaching experience, and educational background. The teachers' data as the participants in this research is outlined in Table 2 .

Table 2. Profiles of Research Participants

\begin{tabular}{|c|c|c|c|c|c|c|}
\hline $\begin{array}{l}\mathrm{Re} \\
\mathrm{g} \\
\text { No } \\
.\end{array}$ & $\begin{array}{l}\text { Educ } \\
\text { ation }\end{array}$ & $\begin{array}{l}\text { Scien } \\
\text { ce } \\
\text { Practi } \\
\text { ces } \\
\text { Exper } \\
\text { ience }\end{array}$ & $\begin{array}{l}\text { Numb } \\
\text { er of } \\
\text { Stude } \\
\text { nts in } \\
\text { Class }\end{array}$ & $\begin{array}{l}\text { Learnin } \\
\text { g } \\
\text { Resour } \\
\text { ces }\end{array}$ & $\begin{array}{l}\text { Attitu } \\
\text { de } \\
\text { towar } \\
\text { ds } \\
\text { scienc } \\
\text { e }\end{array}$ & $\begin{array}{l}\text { Motivati } \\
\text { on }\end{array}$ \\
\hline 1 & 1 & 3 & 15 & 1 & Good & High \\
\hline 2 & 2 & 3 & 10 & 1 & Good & High \\
\hline 3 & 1 & 3 & 15 & 2 & Fair & Medium \\
\hline 4 & 3 & 1 & 14 & 2 & Fair & Medium \\
\hline 5 & 3 & 1 & 12 & 2 & Fair & Medium \\
\hline 6 & 1 & 2 & 15 & 1 & Good & High \\
\hline 7 & 2 & 2 & 15 & 2 & Good & High \\
\hline 8 & 2 & 3 & 15 & 2 & Fair & Medium \\
\hline 9 & 1 & 2 & 13 & 1 & Good & High \\
\hline 10 & 1 & 3 & 14 & 2 & Good & High \\
\hline 11 & 3 & 1 & 14 & 2 & Fair & Medium \\
\hline 12 & 2 & 3 & 15 & 1 & Good & High \\
\hline
\end{tabular}

Remarks:

Education: 1 = Bachelor degree in Early Childhood Education; 2 Bachelor degree in non Early Childhood Education; 3 = not having bachelor degree yet

Teaching experience (Science practices): $1=2 \mathrm{x}$ a month; $2=3-4 \mathrm{x}$ a month; $3=>4 \mathrm{x}$ a month Learning resources: $1=$ in and out of class; $2=$ in class

\section{FINDINGS AND DISCUSSIONS OF RESEARCH}

The observation process reveals several perspectives in how the teachers understand and support the children in obtaining knowledge and in playing the role of young scientists. The results of observation and discussions with the teachers during FGD shows that the success of teachers in managing the science 
learning depend much on their teaching experiences and practices, attitude and motivation in conducting the science learning, the teachers' knowledge of science, and educational background. The analysis result shows that the effort to understand and assist the children to become scientists is conducted by the teachers through these activities.

\section{1) Preparing the materials of science learning Every time a science learning activity is} conducted, the first thing that a teacher must do is to prepare the required materials. All teachers formulate what to be done and provide examples of what to do. The activities teachers' based on knowledge about science learning for early childhood. Besides that, the activities teachers' also were based on understanding toward planing the activities with consideration of children interest, abilities and experiences. All teachers formulate what to be done and provide examples of what to do. In learning about "Trees", for instance, the teachers have prepared the school yard that the students will come to in order to do the observation. The teacher begins by telling the stories about trees, the trees around the kindergarten, and informing the students that they will be brought out to the yard to observe the trees and the children themselves may determine which tree to observe. The required materials for the activity are prepared according to the number of the pupils and are distributed according to their uses. The materials for group activities be given based on the groups while materials for individual activities be given according to the number of individuals using them. Constructivist classrooms are designed to promote the transformation and internalization of new information by learner (Brooks \& Brooks, 1993). The teachers are playing the important role to assist children to think critically and creatively. The teachers also encourage the children who have not understood which activity to do or which material to use.

\section{2) Children observation}

Observation is conducted to discover the children's interests, needs, and understanding. Observation do with them in ways that support their functioning, learning, and thinking in cognitive, social, physical, and emotional areas of development. Nine teachers actively observed the children's activities and made observation notes using the checklists and open or anecdotal records. The records consisted of things such as whether the children touched the leaves of the observed trees and gestures during the observation of the leaves. What do the children can did better support these processes. Eight teachers completed the notes after the learning had been conducted. Three teachers (3.132; 5.312; and 12.231) have not conducted the careful observations yet. Recordings were not completed specifically towards the individuals and instead they were made in general. Such things would hinder the teachers during the reporting of the children's development. These results indicate that there are difficulties teachers conducting the assessment. FGD results show that they have difficulty making the instrument and taking notes in detail. Besides that, Children are unique and complex and thus often difficult to comprehend (George \& Hall, 2005).

\section{3) Asking questions}

Asking questions becomes one of the most important aspects of early childhood education. When the teachers ask questions, it is important to observe the questions asked and the problems inquired in those questions. The content of the questions is expected to guide the children to focus on gaining the knowledge (Ali, 2005). The questions may be asked when the children come for help; the teachers may respond by asking the right questions and by challenging the children (Christine \& Britain, 2003). This type of question is also known as guided question (Muslichach, 2006). The analysis result shows that none of the teachers have managed to ask questions in line with the required characteristics for science learning. The questions asked leaned towards the mastery of materials which, in turn, put the children under pressure and reduced or even eliminated their focus. Those questions should have challenged the children to explore the objects.

\section{4) Organizing the environment}

Organizing the environment is one of the key components in determining the success of learning in constructivist approach (Christine \& Britain, 2003). The organization of the environment in this research was conducted in two learning environments, which were in and out of class (indoor and outdoor). Both environments might be alternately used or only one. Both environments needed to be organized in order to help the children concentrate or focus on the learning activities. The organization of the learning environment was not merely related to the directly used materials; it was 
also related to the supporting components such as pictures and lightings. The teacher needed to design the placement of materials in order to attract the attention of the children. As much as $59 \%$ of teachers conducted the environmental organization, meanwhile the rest merely focused on organizing the materials and tools related to the learning activities. For example, during the learning activity of making orange juice, the teacher merely organized the fruit, juicer, and glasses. The pictures around the classroom were not organized.

\section{5) Managing the social interaction}

Managing the social interaction facilitates the interaction among the teacher and children and among the children. The research result shows that there are reciprocal interactions between the behavior of the teachers and the children depending on the size of the class. The participating teacher conducted grouping such as organizing the class into three groups consisting of 14 to 15 children.

Meanwhile, classes with less than ten students used the individual approach. The children sat forming a circle and creating the freedom of movement; meanwhile classes with more than 10 students put the children in groups. Therefore, there were 2 or 3 groups in the classroom.

\section{6) Documenting}

The teacher has the responsibility to compile, organize, utilize, and share information related to early childhood education especially for the development of the children. The analysis result shows that documentation was conducted by $59 \%$ participating teachers in this research, while the remaining $41 \%$ conducted the documentation but merely gathered the data without compilation and then shared it; including sharing it to the parents. The data shared to the parents were often in the form of analysis result without any supporting document or evidence.

\section{7) Developing the learning culture}

Every individual (teacher, child, principal, and parent) has his or her own habit and such habit influences the learning. In order to develop the learning environment, the teacher needs to manage the interaction in learning so that a pleasant learning environment is created in supporting various learning activities.

\section{8) Developing theories}

In this part, the teacher needs to be capable in playing the role of a scientist to assist the children to become scientists. In this part, the teachers still struggled to realize their roles in such activities that that will help the children to become scientists. Based on the data investigation in FGD, it was discovered that the teachers tended to ignore this part. The teachers still struggled to play the role of a theory builder in learning. Based on the complete observation data analysis result and interview during the FGD, the roles of the teacher may be concluded as outlined in Table 3.

Table 3. The Effort to Understand and Assist the Children as Scientists by Participants through the Constructivist Approach

\begin{tabular}{|c|c|c|c|c|c|c|c|c|c|c|c|c|}
\hline \multirow{2}{*}{ Efforts } & \multicolumn{12}{|c|}{ Characteristics of Research Participant Teachers } \\
\hline & 1.131 & 2.231 & 3.132 & 4.312 & 5.312 & 6.121 & 7.222 & 8.232 & 9.121 & 10.132 & 11.312 & 12.231 \\
\hline $\begin{array}{l}\text { Preparing learning } \\
\text { materials }\end{array}$ & & & & & & & & & & & & \\
\hline $\begin{array}{l}\text { Children } \\
\text { Observation }\end{array}$ & & & & & & & & & & & & \\
\hline Asking questions & & & & & & & & & & & & \\
\hline $\begin{array}{ll}\begin{array}{l}\text { Organizing } \\
\text { environment }\end{array} & \text { the } \\
\end{array}$ & & & & & & & & & & & & \\
\hline $\begin{array}{l}\text { Managing the } \\
\text { social interaction }\end{array}$ & & & & & & & & & & & & \\
\hline Documenting & & & & & & & & & & & & \\
\hline $\begin{array}{l}\text { Developing the } \\
\text { learning culture }\end{array}$ & & & & & & & & & & & & \\
\hline
\end{tabular}


Remarks:

1) The first number is the respondent number

2) The second number is the education level 1= Bachelor degree in Early Childhood education; $2=$ Bachelor degree in nonEarly Childhood education; 3 = no degree yet

3) The third number is the experience in science practices $1=2 \mathrm{x}$ a month; $2=3-4 \mathrm{x}$ a month; $3=>4 \mathrm{x}$ a month

4) The fourth number is the learning resources $1=$ in and out of class; $2=$ in class

From Table 3, it is discovered that teachers with positive attitude and high motivation in conducting the science learning activity with the constructivist approach will be successful in helping the children to become young scientists. The teacher has the power to actively engage as scientists in learning activity [4]. For example, during the activity of observing the "Trees" in the kindergarten yard, the teacher managed to encourage the student to actively conduct the observation. However, such observation have yet to be guided specifically so that the children have not learned the concepts of textures, forms, sizes, and colors of the trees yet. The teacher has not been able to ask guided questions such as "Look at this tree bark, touch and feel it. What about that tree bark? Let's touch and feel it again." The teachers have not been able to assist the children in such guided questions and, thus, have not successfully guided the children yet to compare and observe the textures. In another situation, a child observed another creature living on the trees such as ants and worms. The child asked, "Miss, look, there are worms. Miss, there are ants". Such questions were not properly responded and instead the teacher merely uttered 'oh yeah?', and even encouraged the child to go back looking at the tree whereas the child had lost interest in it. The teacher should have guided children to look at what the ants or the worms were doing, and the child might mention that the tree served as a 'home' to the ants or worms. When such thing happens, the child has the opportunity to understand the concept of roughness, softness, tallness, lowness, bigness, and smallness. The child may also understand the concept of worms, ants, and the child may understand the concept of 'home'. In the next day, when shown the cards with the pictures of worms and ants in them, the child may recall the memory of the tree that had texture, size, form, and color. And when the teacher mentions the word 'ant' during the next day, the child recalls the characteristics of the tree (Bruner Theory).

\section{CONCLUSION}

The early childhood educators need to understand and help the early childhood students to become young scientists in science learning activities through the constructivist approach which consists of eight activities; although, in reality, only a handful of tasks that the teachers have managed to complete in learning practices. The teachers have not realized their roles through detailed planning, especially those teachers without undergraduate training. Moreover, the teachers were not used to conducting learning activities in science and as scientists.

This research has some limitations. Such limitations include the limited number of participants. For the next stage, this research will be followed up by expanding the samples and more detailed and comprehensive data collecting instruments.

The characteristics of children with vast amount of curiosity and individuals who are able to obtain their own knowledge need to be facilitated through various learning activities which will give the opportunities to observe, explore, and investigate. The availability of teachers with scientific sensitivity and the ability to play the role of scientists are necessary to encourage the studies of the curriculum and pedagogy in order to help the early childhood students, not only in scientific aspects but also in holistic personal development so that we may have children who are healthy and smart and are of good characters with the ability to face and overcome life's problems.

\section{REFERENCES}

Ali, Nugraha,. (2005). Pengembangan pembelajaran sains pada anak Usia Dini. Jakarta: Universitas Terbuka

Bowman, Barbara T.; Donovan, M. Suzanne; \& Burns, M. Susan (Eds.).(2001).Eager to Learn: Educating Our Preschoolers. Washington, DC: National Academy Press

Christine, Chaille\&Lory, Britain.(2003).The Young child as scientist a constructivist approach to 
early childhood science education. Boston: Pearson Education

Donna, M. Plummer, Jeannie MacShara, and Skila King Brown.(2006). The Tree of life students began to make connections between humans and their actions and the rain forest and other environments, An NSTA Press Journals Collection Start Young! Early childhood science activities, Arlington Virginia: NSTApress National Science Teacher Association

Dunkin, Michael J\& Biddle, Bruce J.(1974).The Study of teaching.USA:Holt, Rinehart and Winston,Inc

Feeney, Stephanie, Doris Christensen, and Eva, Moravik,.(2006). Who am I in the lives of children seventh edition. Columbus, Ohio: Pearson Merril Prentice Hall

George Forman \& Ellen Hall, (2005) Wondering with Children: The Importance of Observation in Early Education, Journal ECRP, Vol 7 No 2

Gunawan, Adi, W. (2004). Genius learning strategy petunjuk praktis untuk menerapkan accelerated learning. Jakarta: Penerbit PT Gramedia Pustaka Utama

Joyce, Bruce and Marsh, Weil.(1996).Models of teaching. Fifth edition. Boston: Allyn and Bacon

Karen Worth.(2010). Science in early childhood classroom: content and process. Seed Paper, Newton, Massachusetts: Center for Science Education, Education Development Center, Inc

Kauchack, Donald P \&Eggen, Paul D.(2008).Learning and teaching Research Based Methods. Boston: Pearson Education Kemp, Jerrold, E. (1985). The Instructional design process. New York: Harper and Row Publisher

Muslichach, Asy'ari,.(2006). Penerapan pendekatan sains - teknologi-masyarakat dalam pembelajaran sains di Sekolah Dasar. Jakarta: Depdiknas Ditjen Dikti Direktorat Ketenagaan

Shannan, MacNair.(2006). Introduction An NSTA Press Journals Collection Start Young! Early Childhood Science activities, Arlington Virginia: NSTApress National Science Teacher Association

Snelbecker, Glenn, E.(1974).Learning theory, instructional theory and psychoeducational design.New York: McGraw-Hill Book Co

Supriadi, Dedi.(2004). Membangun bangsa melalui pendidikan. Bandung: PT Remaja Rosda karya 